\title{
Price Effects of Dutch Hospital Mergers: An Ex-post Assessment of Hip Surgery
}

\author{
Ron G. M. Kemp • Nikki Kersten • \\ Astrid M. Severijnen
}

Published online: 16 May 2012

(C) The Author(s) 2012. This article is published with open access at Springerlink.com

\begin{abstract}
This study analyses price effects of six mergers in the Dutch healthcare industry. We investigate whether the merging hospitals raised their prices for hip surgery after the merger and, if so, how patients react to this higher price. For seven of the twelve hospitals involved, we found a statistically significant price increase for hip surgery, for three hospitals we found a significant price decrease. There is no clear relationship between price changes of hip surgery and changes in travelling behaviour of patients post merger.
\end{abstract}

Keywords Competition law enforcement - Merger control · Ex-post studies . Healthcare

JEL Classification $\quad \mathrm{D} 49 \cdot \mathrm{L} 40 \cdot \mathrm{L} 50 \cdot \mathrm{L} 80$

\section{Introduction}

Mergers of hospitals and the assessment of these mergers by competition authorities often get a lot of attention by both public and politics. Discussions concentrate on the

R. G. M. Kemp $(\bowtie) \cdot$ N. Kersten

Office of the Chief Economist, The Netherlands Competition Authority, Muzenstraat 81,

2511 WB The Hague, The Netherlands

e-mail: ron.kemp@nma.nl

R. G. M. Kemp

Wageningen University, Wageningen, The Netherlands

\section{A. M. Severijnen}

Department for Competition and Consumer Policy, Ministry of Economic Affairs, Agriculture and Innovation, The Hague, The Netherlands

e-mail: a.m.severijnen@minez.nl 
effect of mergers on quality, accessibility, scale inefficiencies and the emergence of market power. In the ex-ante assessments of these mergers most attention is given to the geographical market delineation.

In the United States, there were over 900 hospital mergers during the period 19952002. Competition authorities challenged only seven of these cases. In court, they lost all seven cases, and most of these losses were because of the geographical market delineation. The courts usually accepted the broad market definition that the parties put forward. Nevertheless, studies that performed ex-post assessments of hospital mergers showed that several hospital mergers did have anticompetitive price-effects. Moreover, in 2005, competition authorities challenged a hospital merger ex-post. In this case, the court accepted the limited geographical market put forward by the competition authorities. This was the first time since the 1980s that the courts ruled in favour of the competition authorities with regard to challenging a hospital merger (Varkevisser and Schut 2009). ${ }^{1}$

Since the gradual introduction of managed competition in the Dutch hospital market in 2004, the NMa has until the end of 2011 assessed twelve hospital mergers. Apart from an intended merger that was cancelled by the merging parties and two merger assessments that are still ongoing, the NMa approved all of the other mergers, mainly because there would be enough competition left on the market after each merger. Some of these decisions have led to a lively debate among policymakers, scholars, and politicians. ${ }^{2}$ The geographical market definition in particular turned out to be one of the focal points of this debate (Janssen et al. 2009). According to some critics, the NMa should, in case of doubt, have chosen for the smaller geographical market instead of for the larger geographical market. Unlike in the U.S., hospital mergers in the Netherlands have yet to be empirically assessed ex-post.

In this study, we perform an ex-post analysis of six mergers involving Dutch hospitals that were approved by the NMa: the Ziekenhuis Hilversum-Ziekenhuis Gooi-Noord merger (hereafter: Tergooiziekenhuizen merger), Erasmus MCHavenziekenhuis Rotterdam merger (hereafter: Rotterdam-hospital merger), Medisch Centrum Alkmaar-Gemini Ziekenhuis merger (hereafter MCA-Gemini merger), St. Lucas Ziekenhuis-Delfzicht ziekenhuis merger (hereafter Ommelander ziekenhuis merger), Ziekenhuis Walcheren-Oosterscheldeziekenhuizen merger (hereafter Admiraal De Ruyter ziekenhuis merger) and Ziekenhuis Bethesda-Scheperziekenhuis merger (hereafter Leveste-Middenveld merger). In particular, the Tergooiziekenhuizen merger, the MCA-Gemini merger and the Admiraal De Ruyter merger have led to much debate and criticism from policymakers, scholars and politicians (see e.g. Janssen et al. 2009). In our analysis, we investigate whether or not the merging hospitals increased their prices for hip surgery, which can be an indication for parties using their increased market power. Moreover, we analyze the travelling behaviour of patients to see whether patients react to a price increase by switching to another hospital.

\footnotetext{
1 This case is FTC_Evanston Northwestern Healthcare Corporation, No. 9315 (FTC May 17, 2005).

2 See for example a special issue of the journal Markt \& Mededinging, No. 2: April 2009, that was entirely devoted to competition in the healthcare sector. Other examples are Kalbfleisch (2009), Reering (2009), Canoy (2008), van Sinderen (2008) and Varkevisser and Schut (2008).
} 
Section 2 provides an overview of the related literature. In Sect. 3, we describe the reforms in the Dutch hospital sector and the process of (hospital) merger control in the Netherlands. The methodology and data are described in Sect. 4. The results are discussed in Sect. 5, followed by the conclusions in Sect. 6.

\section{Literature Overview}

The economic literature covers a large number of empirical studies on the effects of mergers on prices. These studies compare the effect of the outcome of either an antitrust intervention or antitrust abstention with the estimated effect of a counterfactual (Don et al. 2008; Niels and van Dijk 2008).

Several quantitative ex-post studies of mergers in the healthcare sector have been conducted over the past years. Most of these ex-post evaluations of hospital mergers originate from the U.S., as competition in the healthcare sector has been introduced there quite some time ago. ${ }^{3}$ Until the beginning of the 2000 s, most of the studies that investigated the effects of hospital mergers used the structure-conduct-performance paradigm. In these studies, the correlation between market concentration and price is employed to assess a merger. Since the 1990s, the studies typically found a positive relationship between concentration and price (see e.g. Dranove et al. 1993; Pautler and Vita 1994), suggesting that hospital mergers would lead to higher prices after the mergers have gone through. Although quite informative, these studies, however, did not reveal any direct evidence of the effects of mergers. Furthermore, the results of these studies depend heavily on the market definition, which in itself is very challenging (Varkevisser et al. 2008). Consequently, in these studies, inaccurate market definitions may have led to incorrect conclusions about the effects of mergers.

Since 2000, comparing pre-merger prices with post-merger prices has been the most common methodology, particularly using the difference-in-differences (DID) approach. One of the major advantages of this methodology is that it does not require any market definition. Accordingly, erroneous conclusions about the effect of a merger, as a consequence of an incorrect market definition, are avoided. Connor et al. (1998) and Krishnan (2001) used DID approaches to assess multiple hospital mergers ex-post. Connor et al. analyzed the change in total patient revenue for all of the 122 hospitals in the U.S. that merged during the period 1986-1994. They found a decrease in costs of $5 \%$ and a price decrease of $5 \%$ for the merging hospitals relative to the control group of non-merging hospitals. They concluded that the decrease in costs is converted into lower prices and the mergers have thus been pro-competitive. Krishnan (2001) examined 22 hospital mergers in Ohio and 15 hospital mergers in California. His analysis took place at the level of case (treatment) types and he showed that, for all case types studied, the price increase for the merging hospitals was higher than for the control group. Moreover, he demonstrated that the price increase was larger for the case types for which the merging hospital obtained a larger market share. Vita and Sacher (2001) showed that the merger analyzed led to significant price increases (around 15 and $30 \%$ ). They also demonstrated that the change in cost did not provide an explanation

3 See for instance the special issue of the International Journal of Economics and Business, 2011, 18(1). 
for the price increases, and that the market share of the merging hospitals in the Santa Cruz County had declined, indicating that a relative quality improvement could not explain the price.

Recently, three articles were published in the International Journal of Economics and Business in which employees of the Federal Trade Commission (FTC) studied the price effects of four hospital mergers that took place in the beginning of the 2000s, using a DID approach. For one hospital merger, Tenn (2011) compared pre-merger to post-merger prices to be paid by three large insurers. He used control variables for observable hospital characteristics, like the type of hospital, the number of beds and the for-profit status of the hospital. One of the merging hospitals had relatively low pre-merger prices, while the other hospital had relatively high pre-merger prices. Post merger, the prices converged to the higher price level. Regression analysis confirmed that the price change of the hospital with lower prices was significantly larger than the average price change, while the price change of the hospital with higher prices was not statistically different from that in the control group. This conclusion held for all insurers.

Haas-Wilson and Garmon (2011) investigated two hospital mergers. For one merger, regression analysis showed that for four of the five managed-care organizations (MCOs), the price increase was large and significant. ${ }^{4}$ In the other merger, regression analysis showed a significant relative price decrease due to the merger for three MCOs, a non-significant relative price increase for one $\mathrm{MCO}$ and a significant relative price increase for another MCO. On average, there was a relative price increase of $4 \%$ in the period 1999-2002.

The results of the evaluation of a hospital merger by Thompson (2011) were mixed. Regression analysis demonstrated that two insurers experienced a significant price increase $(>50 \%)$, one insurer had a significant price decrease $(-29 \%)$, whereas another insurer had a small price increase compared to the control group.

\section{Hospital Mergers in the Netherlands}

\subsection{Introduction}

The NMa, established in 1998, enforces fair competition in all sectors of the Dutch economy. A part of its responsibility is ex-ante assessment of mergers. During the period of 1998-2003, before the major reforms in the healthcare sector had been introduced, several hospital mergers were notified at the NMa for assessment. The conclusion of the subsequent reviews by the NMa was that actual competition between hospitals was not yet possible due to price and supply regulation (NMa 2004; Varkevisser et al. 2008) and therefore, such mergers could not restrict competition. The NMa therefore decided to approve these hospital mergers without carrying out substantive assessments.

\footnotetext{
4 A MCO is a health organization that finances and delivers health care using a specific provider network and specific services and products.
} 
Table 1 Merging hospitals in the Netherlands (till 31/12/2011)

\begin{tabular}{|c|c|c|}
\hline Merging hospitals & Date & Decision \\
\hline Juliana Kinderziekenhuis/RKZ-Leyenburg & $28-1-2004$ & No license required \\
\hline Ziekenhuis Hilversum-Ziekenhuis Gooi-Noord & $15-12-2004$ & License is required \\
\hline (Tergooiziekenhuizen) & $8-6-2005$ & License issued \\
\hline Erasmus MC_-Havenziekenhuis Rotterdam & $8-6-2005$ & No license required \\
\hline Ziekenhuis Walcheren-Oosterscheldeziekenhuizen & $18-11-2005$ & License is required \\
\hline \multirow[t]{3}{*}{ (Admiraal De Ruyter Ziekenhuis) } & $16-8-2006$ & Withdrawn \\
\hline & $8-8-2008$ & License is required \\
\hline & $25-3-2009$ & License issued, with remedies \\
\hline Laurentius Ziekenhuis-St. Jans Gasthuis & $19-2-2007$ & $\begin{array}{l}\text { No license required, merger is not } \\
\text { implemented }\end{array}$ \\
\hline Vlietland Ziekenhuis-MC Rijnmond Zuid & $19-7-2007$ & $\begin{array}{l}\text { No license required, merger is not } \\
\text { implemented }\end{array}$ \\
\hline MC Alkmaar-Gemini Ziekenhuis & $13-9-2007$ & No license required \\
\hline $\begin{array}{l}\text { St. Lucas Ziekenhuis-Delfzicht Ziekenhuis } \\
\text { (Ommelander Ziekenhuis) }\end{array}$ & $29-4-2008$ & No license required \\
\hline $\begin{array}{l}\text { Ziekenhuis Bethesda-Scheperziekenhuis } \\
\text { (Leveste-Middenveld merger) }\end{array}$ & $21-8-2009$ & No license required \\
\hline Zorggroep Noorderbreedte-Ziekenhuis De & $6-9-2010$ & License is required \\
\hline Tjongerschans & $28-9-2011$ & License issued \\
\hline $\begin{array}{l}\text { Orbis Medisch Centrum-Atrium Medisch Centrum } \\
\text { Parkstad }\end{array}$ & $5-9-2011$ & $\begin{array}{l}\text { License is required, assessment } \\
\text { process is ongoing }\end{array}$ \\
\hline TweeSteden Ziekenhuis-St. Elisabeth Ziekenhuis & 20-12-2011 & $\begin{array}{l}\text { License is required, assessment } \\
\text { process is ongoing }\end{array}$ \\
\hline
\end{tabular}

However, in 2004, the NMa concluded that, given the legislation at that time, hospitals could compete with respect to quality, service and supply. In addition, after the introduction of the competitive segment in 2005, competition also became possible with respect to price. From then onwards, the NMa has assessed hospital mergers for their effect on competition. The NMa has assessed ten hospital mergers since 2004, two merger are currently being assessed, see Table 1 . In most cases, the merging hospitals were close competitors in a geographical sense. Except for the Admiraal De Ruyter ziekenhuis merger, the NMa approved all hospital mergers unconditionally (or is still in the assessment process), primarily because of the fact that there would be enough competition left on the market after the merger. The Admiraal De Ruyter merger was approved conditional on behavioural commitments. The commitments concern amongst others a price cap in which the prices in the competitive part are not allowed to increase more than the national average price increase. Two of the approved mergers (Laurentius Ziekenhuis-St. Jans Gasthuis and Vlietland Ziekenhuis-MC Rijnmond Zuid) were not implemented by the merging parties, the hospitals remain independent. 


\subsection{Reforms in the Dutch Healthcare System}

In this section, we describe the institutional framework of the Dutch healthcare sector, since it is important to take this into account when performing ex-ante and ex-post assessments of hospital mergers.

Over the last 5 years, a number of major reforms took place in the Dutch healthcare sector. The policy objectives of the Dutch government are to keep healthcare affordable, accessible and of high quality. This is done by a gradual introduction of a system of managed competition.

With regard to hospitals, the first steps were the introduction of a system of so-called diagnosis-treatment combinations (DBCs), as well as the introduction of a competitive segment of hospital care. A DBC describes the care for a patient in four codes: care requirement, care type, diagnosis and treatment. In this way, a DBC covers the entire treatment process a patient goes through, from the first appointment to the last check. The DBC diagnosis codes are connected to the international ICD10-codes. The DBC system was introduced in 2005, and it forms a unequivocal negotiation and declaration language: DBCs are the same in all Dutch hospitals and can be seen as relatively homogeneous treatments. For a carefully selected small group of DBCs, namely DBCs that deal with uncomplicated, elective (non-acute) outpatient hospital care, prices, quantities and quality were made subject to bargaining between insurers and hospitals. This competitive segment of hospital care is called the B-segment. All other treatments are part of the non-competitive segment (A-segment). For each treatment in the B-segment, insurers negotiate on the price with hospitals. In 2005, $8 \%$ of the hospital care was part of the competitive segment. The competitive segment was expanded by including more treatments to $20 \%$ of the hospital care in 2008 , to $34 \%$ in 2009 (NZa 2008) and to $70 \%$ in 2012.

In 2006, the Dutch Healthcare Authority (NZa, previously College Tarieven Gezondheidszorg/ZAio) was established, which is the sector-specific regulator for all healthcare markets in the Netherlands. The NZa promotes quality, accessibility and affordability in the healthcare sector and can provide the NMa with opinions in hospital merger cases with respect to these three aspects of health care.

Since January 1st, 2006, the new Health Insurance Act has been in effect, legally requiring all residents of the Netherlands to take out healthcare insurance and to get at least a basic health insurance package. This package consists of basic medical and hospital care. The coverage of this package is the same for each resident, although the fee may differ per insurer. Healthcare insurers are obliged to accept all applicants for the basic package, and they have to charge the same price to each insured person. As a result, price discrimination and risk selection are not allowed regarding the basic package. To compensate insurance companies for actuarially predictable health expenditure differentials induced by socio-demographic factors, such as age, sex, income, location and prior health care consumption (chronic pharmaceutical dependencies and prior hospitalization), a sophisticated risk adjustment system has been introduced. This risk adjustment system was meant to level the playing field for health insurers and, as a consequence, to enable price competition (see Schut and van de Ven 2005). 


\section{Methodology}

\subsection{Model}

To study the ex-post price effect of the hospital mergers, we use the difference-indifferences (DID) approach, which is based on a 'before-after' comparison (Hunter et al. 2008). This method is also used in previous studies on the price effect of hospital mergers (see e.g. Tenn 2011; Thompson 2011). We include all other hospitals in the Netherlands in the regression, in which the price is affected by the same factors, but not by the merger. In order to distinguish the effect of the mergers, it is necessary to control for factors (so called observable characteristics) that can cause a price change, such as the number of specialists and the competition conditions. Other factors which are more difficult to quantify, like technological developments and changes in the regulatory framework are also controlled for in the DID approach. We assume that the merging hospitals are influenced by general technological developments and regulatory reforms to the same degree as the other hospitals in the Netherlands are.

Typically, ex-post merger studies use a model of the form (Tenn 2011: 71):

$$
\ln p_{j}=X_{j} \beta+\gamma_{h j}+\alpha \text { PostMerger }_{j}+\theta\left(\text { PostMerger }_{j} * m_{j}\right)+\omega_{j}
$$

The dependent variable $p_{j}$ is the price for patient $j, X_{j}$ represents the set of patient characteristics and $\gamma_{h j}$ is the fixed effect for hospital $h$. The variable PostMerger ${ }_{j}$ is a dummy variable that has value one if a patient enters a hospital in the post merger period. Dummy variable $m_{j}$ is equal to one if the hospital is one of the merging hospitals. The coefficient $\theta$ is the DID parameter and reflects the difference between the price change of the merging hospitals and the price change of the control group, after controlling for the observable characteristics $\left(X_{j}\right)$.

Tenn (2011) and Thompson (2011) use a two-step approach to avoid downwardbiased standard errors (Bertrand et al. 2004). In the first stage, the average price change for each hospital is estimated, while controlling for patient characteristics. In the second stage, the difference between the price change of the merging hospitals and the price change of the control group of hospitals is estimated, controlling for hospital characteristics that explain variation in each hospital's post merger price change. In our analysis, we can aggregate the patients' level data to insurer-hospital level data without a loss of information as the prices are the same for all patients that have the same insurer and that enter the same hospital. Therefore, it is not necessary to control for patient characteristics, as our level of analysis is the hospital-insurer level and patient characteristics do not affect DBC-prices. ${ }^{5}$

We determine the price effect of the merger by performing a fixed effect panel regression. We control for hospital characteristics that are not constant over time like the number of specialists and quality. Furthermore, we include time dummies to control

\footnotetext{
5 In contrast, Tenn (2011) and Thompson (2011) need to control for patient characteristics, like age, sex and type of insurance. This is due to the differences between the American health insurance system and the Dutch system. We have also employed an analysis in which we corrected the actual prices for patient characteristics (age and sex), the results have the same magnitude as the results reported in this paper.
} 
Table 2 Control variables for observable hospital characteristics

\begin{tabular}{|c|c|}
\hline Control variable & Description \\
\hline $\mathrm{HHI}$ insurers $^{\mathrm{a}}$ & Herfindahl-Hirschman Index of insurers, per province \\
\hline Medical specialists & Number of medical specialists working in the hospital \\
\hline Orthopedists & Number of orthopedists working in the hospital \\
\hline Outpatient cases & Relative number of outpatient cases in the hospital \\
\hline Quality $\mathrm{AD}^{\mathrm{b}}$ & $\begin{array}{l}\text { Score on yearly Algemeen Dagblad (AD, a Dutch } \\
\text { newspaper) survey on hospital quality }\end{array}$ \\
\hline
\end{tabular}

a This information is obtained from Monitor Zorgverzekeringsmarkt 2008, by NZa

$\mathrm{b}$ This information is obtained from Algemeen Dagblad, AD Ziekenhuis Top 100 (http://www.ad.nl/ ziekenhuistop100)

for time fixed effects and control for unobservable hospital characteristics by means of including a control group. ${ }^{6}$ The unit of analysis is the hospital-insurer combination.

So we estimate a model of the form:

$$
\begin{gathered}
\ln p_{h i t}=\alpha+z_{h t}^{\prime} \beta+\sum_{j=1}^{m_{h}}\left(\theta_{h, t+j} \text { Merger }_{h, t+j}\right)+\xi_{t}+\eta_{h i}+\varepsilon_{h i t} \\
t=2005, \ldots, 2010
\end{gathered}
$$

where $\ln p_{h i t}$ is the price per hospital $\mathrm{h}$ and insurer $i$ combination in year $t, \alpha$ is the constant, $z_{h t}^{\prime}$ reflects the observable hospital characteristics in year $t$ (see Table 2). The coefficient $\theta_{h, t+j}$ is the DID parameter, reflecting the price effect separate for each merging hospital, for each year after the merger approval. Nerger $_{h}$ is a dummy variable that is equal to one for the post merger year(s) and zero otherwise, $\xi_{t}$ represents the time fixed effect parameter and $\eta_{h i}$ is the hospital-insurer fixed effect parameter.

The analysis is done for hip surgery in the competitive segment, and for one specific disorder in particular, i.e. the abrasion of the hip, arthrosis. This is a disorder that is very common among seniors and is a fairly homogeneous treatment. The treatment includes more than $95 \%$ of total hip treatments in the 2005 competitive segment. We concentrate on this treatment because hip treatments constituted a large share of the total revenue in the 2005 competitive segment of hospital care in the Netherlands (20\% in 2005). ${ }^{7}$ Furthermore, hip surgery is performed in almost all hospitals in the Netherlands, so a large control group can be constructed. Finally, hip surgery is typically performed in hospitals and not in independent treatment centres. ${ }^{8}$ Analysis for the whole competitive segment is difficult as the competitive segment is expanded

\footnotetext{
6 Moreover, our control group is relatively large, so we do not have the problem that the obtained estimates are imprecise as a consequence of a small control group (see e.g. Tenn 2011, p. 72).

7 See Monitor Ziekenhuiszorg 2004, Monitor Ziekenhuiszorg 2005, Monitor Ziekenhuiszorg 2006, Monitor Ziekenhuiszorg 2007, by NZa.

8 Independent treatment centers are small outpatient treatment centers that are allowed to enter the market since 1998. These independent treatment centers are only allowed to provide elective (no acute) hospital care (Halbersma et al. 2007).
} 
over time and there are some changes in the content of some DBC treatments making price comparison over time impossible.

\subsection{Data}

The analysis is based on a NZa dataset of treatment, prices, quantities and patient characteristics for all hospitals in the Netherlands. The level of analysis is the hospital-insurer combination level. We have data for the period 2005-2010. This implies that the price effect of two approved mergers [Juliana Kinderziekenhuis-RKZ Leyenburg (2004) and Zorggroep Noorderbreedte-Ziekenhuis De Tjongerschans (2011)] cannot be included in the analysis. Furthermore, two approved mergers Laurentius Ziekenhuis-St. Jans Gasthuis and Vlietland Ziekenhuis-MC Rijnmond Zuid were not implemented by the merging parties. Therefore, we test the price effect of six mergers which were approved in 2005, 2007, 2008 and 2009.

The control group consists of all other hospitals in the Netherlands that perform hip surgery in the period 2005-2010. In total, we have 4,851 observations. We control for observable differences between the hospitals by including several control variables (see Table 2). ${ }^{9}$ Most variables have been obtained from the NZa unless otherwise stated.

The number of medical specialists indicates the size of the hospitals and to what extent they have grown during this period. ${ }^{10}$ The relative number of outpatient cases and the number of orthopedists control for the focus and expertise of the hospital with respect to the competitive segment in general and to hip surgery in particular. Outpatient cases shows to what extent hospitals focus on the competitive segment, relative to the non-competitive segment during this period. ${ }^{11}$ Orthopedics is the medical specialism that deals with hip surgery. An increase of the number of orthopedists may imply, for example, lower price increases (economies of scale), or higher price increases (more expertise and higher quality). The Herfindahl-Hirschman Index insurers $(\mathrm{HHI})^{12}$ control for the competition and negotiation circumstances. A larger HHI of the insurers indicates a stronger bargaining power which can lead to lower price increases. Finally, we control for overall quality at hospital level (Quality AD), as there is no specific and reliable quality measure for hip surgery available. An relative increase in quality may lead to relatively higher prices, while decreased quality may lead to relatively lower prices. Quality is measured by the score in the annual survey of Dutch newspaper Algemeen Dagblad (AD) on quality, which consists of twenty-six

\footnotetext{
9 We wanted to include the length of the waiting lists as a control variable as well, but this was not possible due to a lack of reliable information.

10 The number of beds may also indicate to what extent the size of hospitals matters, but this measure only takes into account inpatient cases. Conversely, a change in the number of medical specialists takes into account both inpatient and outpatient cases. Moreover, the number of beds of the hospitals has virtually been constant during the period of our investigation.

11 The major part of the treatments in the competitive segment is outpatient cases.

12 To calculate the HHI, we need to determine the relevant geographical market. For the HHI insurers, we define the market as province. The HHI is calculated by summing the squares of the market shares of the insurers per province.
} 
Table 3 Price index (hip surgery) of merging hospitals, pre and post merger (national, excluding merging parties $=100$ )

\begin{tabular}{lrrrrrr}
\hline & 2005 & 2006 & 2007 & 2008 & 2009 & 2010 \\
\hline National (excluding merging hospitals) & 100.0 & 100.7 & 101.7 & 104.2 & 104.3 & 104.5 \\
Ziekenhuis Gooi-Noord (2005) & 101.3 & 103.2 & 104.6 & 106.7 & 107.7 & 111.7 \\
Ziekenhuis Hilversum (2005) & 97.4 & 102.7 & 104.6 & 106.7 & 107.7 & 111.7 \\
Havenziekenhuis Rotterdam (2005) & 104.0 & 113.0 & 106.2 & 105.7 & 105.9 & 104.3 \\
Erasmus MC (2005) & 104.7 & 101.5 & 103.8 & 111.8 & 111.3 & 115.3 \\
MC Alkmaar (2007) & 96.3 & 101.4 & 102.9 & 98.8 & 121.7 & 106.9 \\
Gemini Ziekenhuis (2007) & 111.0 & 112.4 & 102.3 & 123.0 & 140.0 & 123.7 \\
Delfzicht Ziekenhuis (2008) & 96.0 & 98.8 & 100.9 & 100.9 & 104.6 & 103.6 \\
St. Lucas Ziekenhuis (2008) & 99.0 & 107.2 & 105.6 & 101.7 & 104.6 & 103.6 \\
Oosterscheldeziekenhuizen (2009) & 102.2 & 99.7 & 100.3 & 101.8 & 104.6 & 102.8 \\
Ziekenhuis Walcheren (2009) & 104.2 & 99.3 & 99.4 & 106.2 & 103.6 & 102.8 \\
Ziekenhuis Bethesda (2009) & 89.3 & 96.4 & 97.8 & & 99.8 & 99.2 \\
Scheperziekenhuis (2009) & 98.9 & 100.9 & 102.9 & 104.0 & 116.3 & 106.8 \\
\hline
\end{tabular}

quality indicators that are formulated by, amongst others, the Netherlands Health Care Inspectorate (IGZ). Examples of these quality indicators are undernourishment, pain after surgery, cancelled operations and patient satisfaction.

\section{Results}

\subsection{Price Development}

Table 3 shows the average price increase for hip surgery in the whole industry (excluding the merging hospitals, $2005=100$ ) as well as for the merging hospitals individually.

Nationwide, there is a price increase of $4.5 \%$ over the 6 years studied. After the merger, Tergooiziekenhuizen, Ommelander Ziekenhuis and Admiraal De Ruyter Ziekenhuis have one price for the different locations, whereas Erasmus MC, Havenziekenhuis Rotterdam, MC Alkmaar, Gemini Ziekenhuis, Ziekenhuis Bethesda and Scheperziekenhuis ${ }^{13}$ use different prices per location.

We have estimated Eq. 2 via a fixed-effect panel analysis (see Table 4). This results in an unweighted price effect. Ideally, the results should be weighted by the number of patients. In a panel setting weighing is, however, difficult; it is not clear which year to use as basis for the weighing scheme and weighing in panel regressions is not included in standard statistical software. We did some robustness checks such as an analysis of the average price effect on the hospital level. The conclusions remain the same except for St. Lucas Ziekenhuis (no significant effect), Oosterscheldeziekenhuizen (significant negative effect) and Scheperziekenhuis (no significant effect). We also performed

\footnotetext{
13 They will formally merge in January 2012. As we only have post merger data for 2010, we do not know whether they have one uniform or different prices per location for 2012 onwards.
} 





regression without the hospital characteristics. The conclusions are the same although the coefficients change slightly. For the Tergooiziekenhuizen, Rotterdam-hospital and MCA-Gemini merger, the positive coefficients become more positive, the negative coefficients less negative. For the Ommelander, Admiraal De Ruyter and the LevesteMiddenveld merger the opposite holds, the positive coefficients become less positive and the negative coefficients more negative.

Of the control variables, Outpatients and HHI insurers are significant, the other control variables are not significant. In the top panel of Table 4, we present the price effect of the merger per post-merger year. This is the price effect compared to the base year(s) and can be interpreted as the price change above/below the national price development. ${ }^{14}$ For instance, for Delfzicht Ziekenhuis, the price effect of the merger in 2009 compared to the average price over the pre-merger years 2005-2008 is an increase of $5.7 \%$. In the bottom panel, the price effect is presented for the pre-merger years and the post merger years. For Delfzicht Ziekenhuis this is the price effect of the merger over the years 2009 and 2010 compared to the average price over the pre-merger years 2005-2008.

The year-effect dummies for Ziekenhuis Gooi-Noord and Ziekenhuis Hilversum all are significant and positive. The regression analysis shows that, even if we control for other factors that may cause a price increase, price increases on average by $3.4 \%$ for Ziekenhuis Gooi-Noord and $4.6 \%$ for Ziekenhuis Hilversum. This price increase is related to the merger.

The year-effect dummies for the Havenziekenhuis Rotterdam and the Erasmus MC are sometimes significant, sometimes not, and are positive as well as negative. In the longer term, the Havenziekenhuis Rotterdam has a negative price effect of $2.6 \%$. For Erasmus MC we see significant positive and negative price effects. The average price effect of $1.2 \%$ over the years is, however, not significant.

All price effects of the MC Alkmaar-Gemini merger are significant and positive but for one. The first year after the approval of the merger by the NMa, MC Alkmaar shows a negative price effect. As the merger is approved in September 2007, it is not clear whether the merger influenced the price negotiations for the year 2008 already. On average, including 2008, the price in MC Alkmaar increased after the merger by $3.5 \%$ more than the national average. The price effects for Gemini Ziekenhuis are even larger, on average $16.4 \%$ with a top of $23.5 \%$ in 2009 .

For the Ommelander merger, there is an average price increase after the merger of $6.6 \%$ for the Delfzicht Ziekenhuis and $2.3 \%$ for St. Lucas Ziekenhuis.

For the Admiraal De Ruyter merger, we have only one post-merger price. As the merger is approved in March 2009, we expect that the merger had an effect on the negotiated prices for 2010. We see a small but insignificant price decrease of $1.0 \%$ for the Oosterscheldeziekenhuizen and a significant price decrease of $2.0 \%$ for Ziekenhuis Walcheren. This is in line with the price cap commitment that the prices are not allowed to increase more than the national average.

Finally, for the Leveste-Middenveld merger, we have two prices. As the merger was approved by the NMa in August 2009, it is not clear whether the 2010 prices

14 The first year after the merger decision may be interpreted as a transition year as the prices for year $t+1$ are negotiated in year $t$. 
are already influenced by the merger. For sake of completeness, we present the prices; Ziekenhuis Bethesda has a price effect of $-0.1 \%$ and Scheperziekenhuis a price effect of $-4.2 \%$.

\subsection{Possible Explanations for the Price Effect}

For six of the twelve hospitals involved, we observe a significant average price increase after the consummated merger ranging form 2.3 to $16.4 \%$. For only three merging hospitals, we see a significant price decrease. In this section, we will discuss possible explanations for these findings.

First of all, the price increases could be the result of an increase in market power. In economic theory, firms set their price to their cost plus a markup that is related to their market power. If two competing companies merge, the competitive constraints that the merging companies exercise on each other will disappear. As a result, the market power of both companies will increase, which result in a higher markup. If this is the case, it is an anti-competitive merger. However, a merger can also result in more efficient operations, i.e. a pro-competitive merger. In that case, the price after the merger remains the same or decreases even (this could be an explanation for the price decrease for Havenziekenhuis and Scheperziekenhuis). If the observed price increases in the six cases is the result of an increase in market power, the competition authority has made a Type II error (approval of an anticompetitive merger). The extent to which (an increase in) market power can be used depends, amongst others, on the willingness of patients to switch to other suppliers. Although patients are not price sensitive because they do not have to pay the price directly (and often do not even observe the price), we would expect to find an effect of the price increase on patient choices as a consequence of channelling of patients by insurers. The insurers have to pay the price and have therefore an incentive to channel patients to relatively cheaper hospitals. We know that selective contracting by the insurers companies and channelling of their patients was not used and/or successful between 2005 and 2010. At the moment some channelling is introduced but it remains to be seen what the effect on patients choices will be. Apparently, the mechanism suggested above didn't work effectively in the period 2005-2010.

A relative price increase may also (partially) be caused by a relative increase in quality (Argue 2009). Merging parties often claim that one of the reasons to merge is to increase the quality of care. If quality increases, the price may increase as well. If the price/quality ratio is lower or remains the same after the merger, the merger may not be anti-competitive. Given constraints of the data (no good measures for the quality of hip surgery), we cannot test to what extent an increase in quality is (partially) the cause of the observed price increase. However, there are some indications that quality cannot explain the (total) price increase. First of all, the overall indicator of quality, the AD score, is not significant. Second, a recent study by Romano and Balan (2011) on quality improvements in the Evaston merger, in which HaasWilson and Garmon (2011) found significant price increases after the merger, do not confirm the merging hospitals claim that quality was improved, i.e. the quality effect after the merger was not significant. Mutter et al. (2011) analyzed multiple hospital 
consolidations during the late 1990s and early 2000 using a similar method and concluded that consolidations had no consistent effect on quality. They found both significant quality improvements and quality reductions, depending on the hospital and quality measure used. In their study, Vita and Sacher (2001) argued that some kind of volume-related quality increases could exist due to the fact that treatments are performed more frequently at the merging hospitals. However, one would expect no price increase from this type of quality increase. Alternatively, there may also be quality improvements due to extra investments or larger resources expenditures (e.g. better but more expensive prosthesis) per patient after the mergers. This type of quality improvement would results in higher cost after the merger. However, Vita and Sacher found no significant increase in the expenses per patient. So they concluded that quality improvements did not fully account for the observed price increases after the merger in their study.

As direct measures of quality are not present, we can look at indirect effects of possible quality changes. For instance, patients do travel for improved quality. Sonneveld and Heida (2011) find for hip surgery that for a standard deviation decrease in the AD score ( 7.3 points), $3.3 \%$ of the patients bypass the nearest hospital. Thus, if the price increase is related to a quality improvement, one can expect the average travelling time of the treated patients to increase. For testing this proposition, we have calculated the average travel time of patients ${ }^{15}$ that have undergone hip surgery in one of the merging hospitals (see Table 5). ${ }^{16}$ The change in absolute terms is relatively small, i.e. most of the times less than $5 \mathrm{~min}$. In relative terms, the change is more relevant, from -12 to $23 \%$.

For the hospitals with a price increase, we see mixed results. For three hospitals, we see an increase in the average travelling time post merger and for the other three hospitals we see a decrease in the average travelling time. For each merger, one merging hospital has an increased and the other a decreased average travelling time post merger.

Besides the travelling time, also a change in quantities can say something about a change in quality. Vita and Sacher (2001) argued that:

“... If the transaction improved the quality of hospital care provided in Santa Cruz County, relative to that provided in hospitals outside the county, we would expect to observe (ceteris paribus) an increase in the proportion of Santa Cruz County residents who seek hospital care within Santa Cruz County. ..." (p. 81).

\footnotetext{
15 For the calculation, we deleted patients with a travelling time longer than $2 \mathrm{~h}$.

16 In the NZa database, the patients are administered to a central administration code of the hospital. After the merger, three hospitals got a new central administration code (Tergooiziekenhuis, Ommelander ziekenhuis and Admiraal De Ruyter ziekenhuis), the other three keep their old separate code. For the first three mergers, it is not possible to see at which location of the merging hospitals the patient is treated. For the Tergooiziekenhuis and Ommelander ziekenhuis, we assume that the patient is treated at his/her nearest location of the merged hospital. This is a lower bound. For the Admiraal De Ruyter ziekenhuis, hip surgeries are primarily performed in location Ziekenhuis Walcheren, except when complications during surgery are expected. In that latter case patients are treated in location Oosterscheldeziekenhuizen. Since the majority of the patient is treated in location Walcheren, we present the average travelling time assuming that all patient are treated in location Walcheren. If we use the minimum traveling time assumption, the travelling time of Oosterscheldeziekenhuizen is 19.75 and of Ziekenhuis Walcheren 13.94 min.
} 
Table 5 Average travel time to hospitals (in minutes) for hip surgery pre- and post-merger
Table 6 Average market shares (\%) for hip surgery pre- and post-merger

For the three hospitals with a new central administration code (Tergooiziekenhuis,

Ommelander ziekenhuis and Admiraal De Ruyter ziekenhuis), we present the combined preand post merger market shares

\begin{tabular}{lll}
\hline Hospital & Pre-merger & Post-merger \\
\hline Ziekehuis Gooi-Noord & 15.31 & 16.29 \\
Ziekenhuis Hilversum & 14.56 & 13.23 \\
Havenziekenhuis & 14.35 & 15.19 \\
Erasmus MC & 22.87 & 26.20 \\
MC Alkmaar & 18.64 & 19.95 \\
Gemini Ziekenhuis & 24.96 & 24.31 \\
Delfzicht Ziekenhuis & 19.01 & 16.67 \\
St. Lucas Ziekenhuis & 14.22 & 17.46 \\
Oosterscheldeziekenhuizen & 20.27 & \\
Ziekenhuis Walcheren & 14.48 & 24.05 \\
Ziekenhuis Bethesda & 22.30 & 19.83 \\
Scheperziekenhuis & 17.28 & 18.12 \\
\hline
\end{tabular}

\begin{tabular}{lll}
\hline Hospital & Pre-merger & Post-merger \\
\hline Tergooiziekenhuizen & 2.81 & 2.19 \\
Havenziekenhuis & 0.66 & 0.67 \\
Erasmus MC & 0.48 & 0.38 \\
MC Alkmaar & 1.47 & 2.45 \\
Gemini Ziekenhuis & 0.80 & 0.81 \\
Ommelander Ziekenhuis & 1.27 & 0.90 \\
Admiraal De Ruyter ziekenhuis & 1.80 & 1.55 \\
Ziekenhuis Bethesda & 0.32 & 0.29 \\
Scheperziekenhuis & 1.09 & 0.86 \\
\hline
\end{tabular}

We have calculated the market shares of the merged hospitals in the national market. If the price increase is associated with an increase in quality, one expects to see a larger market share. For the Tergooiziekenhuizen and the Ommelander Ziekenhuis this is not the case: the market share decreases. For MC Alkmaar, we see a large increase in market share, which might indicate an increase in quality, whereas for Gemini Ziekenhuis, the increase is very small ( $\Delta$ market share $=0.01)$ which is in no relation with the average price increase of $16.4 \%$ (Table 6 ).

A third explanation for the higher prices can be higher costs after the merger as a result of scale diseconomies, for instance caused by increased bureaucracy. Blank et al. (2011) found empirical evidence that when the hospital production in the Netherlands increases by $1 \%$, the costs increases by $1.23 \%$ and claim, since they have scale diseconomies, the increasing scale of hospitals can only be explained by an incentive to create market power as a result of their scale. If this is the reason for the price increases, the mergers are inefficient. Normally, such a result is not prevented by the merger control rules but primarily a risk for the merging parties. However, because 
of the impact of inefficient mergers in healthcare on public interest, the Dutch government will introduce additional requirements for healthcare mergers which intend to prevent such outcomes. ${ }^{17}$

A fourth explanation could be that the prices of the merging hospitals were below the national average in the year of the merger approval. This especially holds for the mergers in 2005, the year of the introduction of the competitive B-segment. For some hospitals, it took a few years after the opening of the market before the negotiators were used to the bargaining process for this competitive segment. Price increases can accordingly indicate improved negotiation skills, i.e. a kind of a learning effect. However, several price increasing hospitals have a pre-merger price above the national average, so this argument does not hold for them. Furthermore, for the mergers of 2007 onwards this effect should not be that relevant anymore.

Finally, the price effect may also be influenced by characteristics of the negotiation process. In most cases, hospitals and insurers do not negotiate on prices of individual treatments but for a whole package of treatments. If this is the case, the price increases may be caused by merely administrative choices (lower prices for hip surgery due to administrative choices before the merger and higher prices for hip surgery after the merger). However, the national average price for hip surgery closely follows the average price development of the whole 2005 B-segment package (except for 2010).

\section{Final Remarks}

\subsection{Conclusions}

In this paper, we have analyzed the (yearly) effect of six hospital mergers in the Netherlands on the prices for hip surgery. For six of the twelve involved hospitals, we observed a significant average price increase after the consummated merger, ranging form 2.3 to $16.4 \%$. For only three hospitals we see a significant price decrease, of which one hospital is 'regulated' by imposed commitments. Several explanations can be adduced for these price increases such as an increase in market power, a relative improvement of quality, increased costs, improved negotiation skills and administrative choices in allocating the total budget. A central point in the NMa decisions is the expectation that patients would travel if competition parameters change. However, patient flows seems not to be influenced by the price increases as we have found no clear relationship between the price change for hip surgery and the travelling behaviour of the hip surgery patients. It seems that patients did not react to the price increase by choosing another hospital and that they are not (effectively) channelled by their insurers either. As a result, some merging hospitals have increased their price and insurers are faced by an overall price increase for hip surgery. Only in a few cases, the merger results in a lower price.

In the MC Alkmaar-Gemini Ziekenhuis merger, the NMa assumed that a merged hospital will use one price for each location, i.e. they will not price discriminate on

\footnotetext{
17 See Brief van de Minister en Staatssecretaris van Volksgezondheid, Welzijn en Sport van 14 juni 2011, Tweede Kamer de Staten Generaal, vergaderjaar 2010-2011, Kamerstukken 32620, Nr 15.
} 
hospital location. This assumption proved to be incorrect for hip surgery as both locations continue to charge different prices for hip surgery. Also in the Rotterdam-merger there are separate prices for hip surgery, although this might be explained by the difference in the type of hospitals (academic vs. a general hospital).

Furthermore, different insurers do pay different prices for hip surgery per hospital and are faced with different price effects as a result of the merger. Sometimes a larger insurer pays a relatively lower price as a competing smaller insurer. However, the opposite also occurs. Thus, there is no clear pattern how the different insurers are influenced by the mergers. It is therefore important to take all insurers into account when assessing the mergers. Also more knowledge on the negotiation processes between the hospitals and insurers is necessary to understand the dynamics that exist after the merger.

Nowadays, most insurers have contracts with almost all hospitals in the Netherlands. Moreover, most patients can choose any hospital they want, as insurers virtually do not channel patients to hospitals that they prefer out of price or quality motives. In theory, the possibility alone to channel patients will give insurers more bargaining power in their negotiations with the hospitals. However, it can only work if the threat of channelling is credible. The observed price increases for hip surgery indicate that the threat has not been credible so far. At the moment, there are signs that selective contracting and channelling will take place in the future although certain plans have been cancelled as well. According to a survey of the NZa, $52 \%$ of healthcare insurers indicated that they have paid 'much more' or 'more' attention to channelling in 2009, relative to the year before (NZa 2009). On the other hand, channelling could be at the expense of consumer freedom of choice. Therefore, consumers who are channelled should be compensated in terms of, for instance, shorter waiting lists, a lower insurance premium or a higher quality.

\subsection{Future Research}

Just like the results of some recent studies of the FTC, this study shows that in some cases there is a substantial post-merger price increase. It is, however, important to be aware of the limitations of this study and be careful when drawing conclusions.

First of all, a relative price increase may (partially) be caused by a relative quality increase (Argue 2009). In the analysis, we controlled for the overall quality level of hospitals (not significant). However, we have no specific quality measure for the hip surgery. Potential indirect quality indicators (average travelling time and market share) do not give indications that there are significant quality changes related to the merger (except for MC Alkmaar). To properly assess the contribution of a change in quality to the price increase, future research should focus on better and more specific quality indicators. Currently, there are a number of attempts to foster the diffusion of information on quality, and especially on the quality of specific treatments. ${ }^{18}$ Moreover, the Netherlands Health Care Inspectorate has started a project, called Zichtbare Zorg,

18 Examples are http://www.kiesbeter.nl, http://www.independer.nl and http://rivm.openrepository.com/ rivm/bitstream/10029/16490/1/260101003.pdf (for hip surgery). 
which, within a couple of years, should lead to a uniform set of quality indicators that is useful for patients. For hospitals, quality can become an additional competition parameter. Future research is encouraged to include these new quality indicators in new ex-post studies on price effects as well as studies on the impact of mergers on the quality of care.

Second, we have focused on only one type of surgery: we did not take into account all other treatments in the competitive segment. Investigating the price change of all treatments in the competitive segment may well provide a different picture. It is, for example, quite common that insurers and hospitals agree on a total budget that hospitals receive annually. Within this budget, the funds that are allocated to specific treatments can be somewhat arbitrary: for some treatments, a relatively high price can be agreed on, while for other treatments, a relatively low price can be agreed on.

Third, as there are administrative delays in declarations and uncertainty over the moment of implementation of the merger, especially the results of the 2009 mergers should be interpreted with care. This especially hold through for the Leveste-Middenveld merger which was approved in August 2009. It is not clear whether this prices of 2010 are already influenced by the approval of the merger.

Acknowledgments We are grateful to the Dutch Healthcare Authority for giving access to the data. We thank Jarig van Sinderen, Henk Don, Aad Kleijweg, Ilaria Mosca, Rein Halbersma, Misja Mikkers, Willem Kerstholt, Krijn Schep, Gerard la Bastide, Frank Pellikaan, Tako Vermeulen, Machiel Mulder, Dennis Fok and the participants of the symposium on the Ex-post Evaluation of Competition Policy in Mannheim (2009) and an anonymous reviewer for their useful comments and suggestions.

Open Access This article is distributed under the terms of the Creative Commons Attribution License which permits any use, distribution, and reproduction in any medium, provided the original author(s) and the source are credited.

\section{References}

Argue, D. (2009). Looking for anticompetitive price effects: FTC's retrospective studies of hospital mergers. Washington, DC: American Health Lawyers Association.

Bertrand, M., Duflo, E., \& Mullainathan, S. (2004). How much should we trust differences-in-differences estimates? Quarterly Journal of Economics, 119(1), 249-275.

Blank, J., Dumaij, A., \& Van Hulst, B. (2011). Ziekenhuismiddelen in verband: een empirisch onderzoek naar productiviteit en doelmatigheid in Nederlandse ziekenhuizen 2003-2009. IPSE studies, Technische Universiteit Delft, Delft.

Canoy, M. (2008). Zorgfusies: gekker moet het niet worden. Markt \& Mededinging, 11(6), 191-192.

Connor, R., Feldman, R., \& Dowd, B. (1998). The effects of market concentration and horizontal mergers on hospital costs and prices. International Journal of Economics and Business, 5(2), 159-180.

Don, H., Kemp, R. G. M., \& van Sinderen, J. (2008). Measuring the economic effects of competition law enforcement. De Economist, 156, 341-348.

Dranove, D., Shanley, M., \& White, W. (1993). Price and concentration in hospital markets: The switch from patient-driven to payer-driven competition. Journal of Law and Economics, 36(1), 179-204.

Haas-Wilson, D., \& Garmon, C. (2011). Hospital mergers and competitive effects: Two retrospective analyses. International Journal of the Economics and Business, 18(1), 17-32.

Halbersma, R., Mikkers, M., Motchenkova, E., \& Seinen, I. (2007). Market structure and hospital-insurer bargaining in the Netherlands. Tilburg: TILEC.

Hunter, G., Leonard, G., \& Olley, G. (2008). Merger retrospective studies: A review. Antitrust, 23(1), 34-40. 
Janssen, M., Schep, K., \& van Sinderen, J. (2009). Fusies van Ziekenhuizen: Het beoordelingskader van de NMa. Markt En Mededinging, 12(2), 44-53.

Kalbfleisch, P. (2009). Misverstand over NMa. NRC Handelsblad. April 16, 2009.

Krishnan, R. (2001). Market restructuring and pricing in the hospital industry. Journal of Health Economics, 20(2), 213-237.

Mutter, R. L., Romano, P. S., \& Wong, H. S. (2011). The effects of US hospital consolidations on hospital quality. International Journal of the Economics and Business, 18(1), 109-126.

Niels, G., \& van Dijk, R. (2008). Competition policy: What are the costs and benefits of measuring its costs and benefits?. De Economist, 156, 349-364.

NMa. (2004). Besluit Juliana Kinderziekenhuis/Rode Kruis ziekenhuis—Leyenburg Ziekenhuis. http:// www.nma.nl/images/3524BCM22-151558.pdf

NZa. (2008). Monitor ziekenhuiszorg 2008, NZa, Utrecht.

NZa. (2009). Monitor ziekenhuiszorg 2009, NZa, Utrecht.

Pautler, P., \& Vita, M. (1994). Hospital market structure, hospital competition, and consumer welfare: What can the evidence tell us?. Journal of Contemporary Health Law \& Public Policy, 10, 117-167.

Reering, A. (2009). NMa onder vuur door fusie in zorg. NRC Handelsblad, April 8, 2009.

Romano, P. S., \& Balan, D. J. (2011). A retrospective analysis of the clinical quality effects of the acquisition of Highland Park Hospital by Evanston Northwestern Healthcare. International Journal of the Economics and Business, 18(1), 45-64.

Schut, F. T., \& van de Ven, W. P. M. M. (2005). Rationing and competition in the Dutch health-care system. Health Economics, 14, 59-74.

Sonneveld, J., \& Heida, J.-P. (2011). Reisgedrag van patiënten. ESB, 96(4623), 702-704.

Tenn, S. (2011). The price effects of hospital mergers: A case study of the sutter-summit transaction. International Journal of the Economics and Business, 18(1), 65-82.

Thompson, A. (2011). The effect of hospital mergers on inpatient prices: A case study of the new Hanover-Cape fear transaction. International Journal of the Economics and Business, 18(1), 91-101.

van Sinderen, J. (2008). Gekker moet het inderdaad niet worden: Een reactie op de column van Marcel Canoy in M\&M. Markt \& Mededinging, 11(6), 200-201.

Varkevisser, M., Capps, C., \& Schut, F. (2008). Defining hospital markets for antitrust enforcement: New approaches and their applicability to the Netherlands. Health Economics, Policy and Law, 3(1), 7-29.

Varkevisser, M., \& Schut, F. (2008). NMa moet strenger zijn bij toetsen ziekenhuisfusies. ESB, 93(4532), 196-199.

Varkevisser, M., \& Schut, F. (2009). Hospital merger control—an international comparison. iBMG working paper W2009.01, Erasmus University, Rotterdam.

Vita, M., \& Sacher, S. (2001). The competitive effect of not-for-profit hospital mergers: A case study. Journal of Industrial Economics, 49(1), 63-84. 